\title{
Protein-Carbohydrate Interaction
}

National Cancer Institute

\section{Source}

National Cancer Institute. Protein-Carbohydrate Interaction. NCI Thesaurus. Code C18963.

Protein-Carbohydrate Interaction is a molecular interaction between protein and carbohydrate molecules. 